\title{
Attitudes of Teacher Candidates Studying in Physical Education and Alternative Teacher Certification Programs towards Teaching Profession
}

\author{
Günay Yıldızer ${ }^{1, *}$, İlker Yılmaz ${ }^{1}$, Dilek Yalız Solmaz ${ }^{1}$, Deniz Şimşek ${ }^{1}$, Dilara Ebru Uçar ${ }^{2}$ \\ ${ }^{1}$ Faculty of Sport Sciences, Eskisehir Technical University, Eskisehir, Turkey \\ ${ }^{2}$ Department of Physical Education and Sport, Anadolu University, Eskisehir, Turkey
}

Copyright $\bigcirc 2018$ by authors, all rights reserved. Authors agree that this article remains permanently open access under the terms of the Creative Commons Attribution License 4.0 International License

\begin{abstract}
The aim of this study was to examine attitudes of physical education and sport teacher candidates, studying in physical education teaching program and alternative teacher certification program in Turkey, towards teaching profession. The sample of this study consisted of 172 physical education teacher candidates in alternative teacher education certificate training in the Faculty of Education, and 179 physical education teacher candidates are continuing their education in the department of physical education and sports teacher education in four different universities in Turkey. "Attitude Scale towards Teaching" was used as data collection tool in this study. The data were examined by descriptive statistics and a two-way ANOVA test. The teacher education program has the main effect on attitudes toward teaching and teacher candidates in physical education department demonstrated significantly higher attitudes compared to alternative teacher education program $p<0.05$. There was an interaction effect of the education program and gender on attitudes, $p<0.05$. It is suggested that revising the time of the education process in alternative teaching programs and subsidize these programs by field experts may lead to better attitude development among physical education teacher candidates in alternative teaching education certificate.
\end{abstract}

Keywords Attitude, Alternative Teacher Education, Physical Education and Sport, Turkey

\section{Introduction}

Teachers, with their guidance and determinative roles, represent a different and specific value among all components of the educational process [1]. In this respect, it is critical to understand which mechanisms are effective in the educational decision-making processes of teachers who are effective in the academic success of the students [2]. The attitude is one of the important components to explicate behaviors of teachers. Attitude is defined as general manners, feelings, and ideas that one poses to other people, objects or events is important [3]. Deryakulu [4] defines the attitude as tendencies of certain human behavior with a holistic structure of individual beliefs. The fact that the teachers' beliefs are influential on the decisions made during the educational process makes it necessary to understand the ways in which the attitudes or belief systems of the teachers change [5].

Pre-service teacher training is very important in the development of certain belief patterns towards the profession, and the main objective of professional teacher education is to systematically change in-class practices, attitudes and beliefs of the teachers in a positive manner [6]. Matanin and Collier [7] mentioned that the four-year teacher education process and the experiences within this process have a critical role in the development of the belief patterns of physical education teachers. However, Jones and Hayes [10] have shown that the teacher education process often fails in changing attitude towards teaching, even though it covers four years. On the other hand, the most important step in attitude change in the teacher education processes based on practice is the teacher candidates to see the transformation of practicum into achievement in the practice [6]. Because of the duration and the interaction with field experts, a linear increase in attitude towards teaching among pre-service teachers was expected [6]. In this respect, it can be considered that the duration and the process of professional teacher education are valuable.

Attitude development process of the teachers is not limited to external factors such as duration and the quality of the educational process are very important, but also intrinsic factors are very important. The reasons and 
motivational sources of becoming a teacher as a lifelong profession are crucial for both developments of teaching skills and attitudes. Öksüzoğlu [9] reported that teacher candidates who selected the teaching profession voluntarily have higher attitude scores than those who selected it reluctantly. Üstüner, Demirtaş and Cömert [10] showed that the teacher candidates who have chosen the teaching profession for internal reasons have a higher average attitude score than those who have chosen the teaching profession for external reasons.

When the attitude towards the teaching profession is considered regarding the process, it is important to examine the "Pedagogical Formation Education Certificate Program" which is an alternative way to existing teacher education programs to become a teacher in Turkey. Comprehending the attitudes of teacher candidates in alternative teacher education programs becomes important, due to the importance of teacher education process on attitude towards teaching [11]. Alternative teaching certification programs are covering a shorter period than the teacher education programs and this issue has been the focus of the discussions on teacher qualifications [12]. Malow-Iroff, O'Connor, and Bisland [13] also criticized the process of alternative teacher certification programs by emphasizing that the main purpose of the alternative teacher education programs considered as alternative teacher education is to train teachers rapidly. Postareff, Lindblom-Ylanne, and Nevgi [14] emphasized that adopting advanced and complex teaching strategies that will provide teaching competence, requires a long educational process and alternative teacher education programs are questioned in this regard.

Yıldızer, Yılmaz, Yalız Solmaz and Şimşek [15] indicated specific differences in teaching styles between physical education teacher candidates from alternative teacher certification programs and physical education programs. They explained that being in the four-year physical education teacher education program and taking field-specific courses from the field experts rather than experts from the other fields may have led to the better development in teaching physical education. Similarly, type of the teacher education program with different attributes might be effective in forming attitudes of physical education teacher candidates towards teaching profession. Thus, it is important to understand whether the attitudes of the candidates qualified as teachers by the "Pedagogical Formation Education Certificate Program" in Turkey towards the profession differ from that of the teacher candidates who have taken content knowledge and pedagogical courses in the Physical Education and Sports Teaching Programs. The purpose of the study was to examine the attitudes of the physical education and sport teacher candidates, studying in physical education teaching program and alternative teacher certification program towards teaching profession by teacher education program and the gender.

\section{Materials and Methods}

\subsection{Research Model}

The aim of the study was to determine the differences in attitudes towards teaching between teacher candidates from two different teacher education programs. In accordance, the causal comparison model was used among qualitative research models which allow researchers attempt to determine the consequences of differences that already exist between groups of individuals [16]. In this study, this model was used to determine the difference between the attitudes of the teacher candidates in the last class of the teacher education program and the alternative teacher certificate programs within the context of the development of physical education and sports teachers. Physical education teacher candidates' attitudes towards teaching were a dependent variable of the study. The teacher education group Anadolu University Ethical Commission approved this study and all participants provided informed consent forms.

\subsection{Study Sample}

The convenient sampling method was used in this study. All participants from physical education departments and alternative teacher education programs were selected from four different universities in the central Anatolian region of Turkey. Participants of the study consist of 172 physical education teacher candidates (66 females, 106 males) in alternative teacher education certificate training in the Faculty of Education and 179 physical education teacher candidates (86 females, 93 males) continuing their education in the department of physical education and sports teacher education.

\subsection{Data Collection Tools}

"Personal Information Form" and "Attitude Scale towards Teaching" were used as data collection tools in this study. Personal information form includes the teacher-training program and gender information. In order to determine the attitudes of the participants towards teaching profession, the "Attitude Scale Towards Teaching", developed for alternative teaching certification students and teaching department students by Erkuş, Sanll, Bağlı and Güven [17], was used as a main data collection tool. Because the development process of the "Attitude Scale towards Teaching" was implemented on teacher candidates from alternative teacher certification program and teaching department, and it was found valid and reliable in both groups, this instrument was chosen in this study. While initially there were 23 items in the scale, the researchers who developed the scale determined that an item is problematic and warned the study team about using it with 22 items. In this study, a 22 item, 5-point Likert 
scale (Strongly Agree, Agree, Neither, Disagree, Strongly Disagree) was used. 13 of the items in the scale are inversely scored. These points were coded again by the researchers before starting the analysis phase. The highest score was 110 , and the lowest score was 22 in the measurement tool. High scores obtained from the measurement tool reflect high attitudes, while low scores reflect low attitudes toward teaching profession. The original study reported Cronbach's Alpha internal consistency coefficient as 0.95 , and Cronbach's Alpha was 0.98 in this study.

After the permits required for data collection were obtained from the universities, researchers visited the universities and applied the data collection tools. Participation in the study was kept voluntary basis. It took approximately 5 minutes to fill out the scale.

\subsection{Data Analysis}

Two-way analysis of variance (ANOVA) was used to determine whether the gender and teacher education programs make a difference in the attitudes towards teaching. The mean and standard deviation values were also examined for independent variables.

In order to carry out the two-way ANOVA analysis, the assumptions of the ANOVA were checked. First of all, Box Plots were drawn separately for each independent variable, and extreme values were tried to be determined. Five of the female participants and 4 of the male participants in the teacher education program were identified as extreme values and excluded from the study. No extreme values were found in the Box Plots were drawn for male and female participants in the alternative teacher education group. Skewness and kurtosis values were within \pm 2.0 for the normality assumptions for each independent variable, and the normality assumption was confirmed [18]. Finally, according to the results of the Levene's test, the variances were not homogeneously distributed for the attitude score representing the dependent variable. Tabachnik and Fidell [19] emphasized that the assumption of homogeneity of variances can be violated in the case that the compared group sizes are close to each other. Two-way ANOVA analysis was used by neglecting this assumption because the group sizes (170-172) were close to each other in this study. The data were analyzed using SPSS 24.0 (IBM, IL). The significance level was accepted as 0.05 in the analysis.

\section{Results}

The results of the two-way analysis of variance conducted to answer the research question "Do the group and gender variables of teacher candidates differ in their attitudes towards the teaching profession?" The attitude scores based on the independent variables and the results of the two-way analysis of variance are presented in Tables 1 and 2 .

When Table 1 is examined, it is seen that female teacher candidates $(100.13 \pm 7.16)$ in the physical education teaching program had the highest attitude level and male teacher candidates $(96.15 \pm 10.58)$ in the same program followed them. The female candidates in the alternative teacher education program presented the lowest attitude level by having the lowest score from the scale (53.65 \pm 32.86$)$, and the male candidates in the same education group had a higher score $(60.06 \pm 31.91)$ than the female candidates in the same group. It was found that the participants in the teaching program (98.05 \pm 9.30 ) have a higher attitude level towards the teaching profession compared to the participants in the training group (57.60 32.34$)$. When the results are analyzed regarding gender, it is observed that female teacher candidates (79.26 \pm 32.36$)$ had higher attitudes towards the profession that the male teacher candidates $(76.53 \pm 30.44)$.

According to the results of the two-way ANOVA, the gender of the group and the participants in the teaching education affects the attitude scores interactively $[\mathrm{F}(1$, $\left.338)=3.97, p=0.04, \eta^{2}=0.012\right]$. When the main effects of the study's independent variables on the attitude scores were analyzed, it was seen that they differed the attitude scores of the teaching education group $[F(1,338)=250.32$, $\left.\mathrm{p}=0.00, \eta^{2}=0.425\right]$. As another independent variable, gender does not differ the attitudes of the teacher candidates towards the profession $[\mathrm{F}(1,338)=0.22, \mathrm{p}=0.64]$. Two-way ANOVA results are presented in Table 2.

Table 1. Attitude Scores According to Teacher Education Group and Gender Variables

\begin{tabular}{cccc}
\hline & $\begin{array}{c}\text { Female } \\
(\mathrm{X} \pm \mathrm{SD})\end{array}$ & $\begin{array}{c}\text { Male } \\
(\mathrm{X} \pm \mathrm{SD})\end{array}$ & $\begin{array}{c}\text { Total } \\
(\mathrm{X} \pm \mathrm{SD})\end{array}$ \\
\hline $\begin{array}{c}\text { Alternative } \\
\text { Teacher }\end{array}$ & $53.65 \pm 32.86$ & $60.06 \pm 31.91$ & $57.60 \pm 32.34$ \\
$\begin{array}{c}\text { Education } \\
\text { Program }\end{array}$ & & & \\
Teaching & & & \\
$\begin{array}{c}\text { Education } \\
\text { Program }\end{array}$ & $100.13 \pm 7.16$ & $96.15 \pm 10.58$ & $98.05 \pm 9.30$ \\
Total $(\mathrm{X} \pm \mathrm{SD})$ & $79.26 \pm 32.36$ & $76.53 \pm 30.44$ & \\
\hline
\end{tabular}

Table 2. Two-Way ANOVA Results of the Attitude Levels of Physical Education and Sports Teacher Candidates According to the Teaching Education Group and Gender Variables

\begin{tabular}{cccccc}
\hline Effect & F & $\begin{array}{c}\text { Hypothesis } \\
(\mathrm{sd})\end{array}$ & $\begin{array}{c}\text { Error } \\
(\mathrm{sd})\end{array}$ & $\mathrm{p}$ & $\eta^{2}$ \\
\hline $\begin{array}{c}\text { Teacher } \\
\text { Training } \\
\text { Group }\end{array}$ & 250.329 & 1 & 338 & 0.000 & 0.425 \\
Gender & 0.218 & 1 & 338 & 0.641 & 0.001 \\
Teacher & & & & & \\
$\begin{array}{c}\text { Training } \\
\text { Group x } \\
\text { Gender }\end{array}$ & 3.965 & 1 & 338 & 0.047 & 0.012 \\
\hline
\end{tabular}

\section{Discussion and Conclusion}

In this study, the objective was determining the difference between the attitudes of teacher candidates in the teacher training programs and alternative teacher 
education certificate programs within the scope of physical education teacher development. It was found that the participants in the physical education teaching program had a higher attitude level towards the teaching profession compared to the participants in the alternative teaching certification group and this difference was statistically significant. The findings of the study revealed that the teacher education group and gender interactively pose a difference in the attitude towards the teaching profession. The female teacher candidates in the alternative teacher education program to have the lowest attitude average and the female teacher candidates in the physical education and sports teaching program to have the highest average score are effective on these results. These results may also be due to the limited opportunities of the female participants in the alternative teacher education group regarding the profession during university education and their attitudes towards teaching in the alternative teacher education courses. When the magnitudes of effect are analyzed, it can be said that the main effect is due to the variable of teacher education group.

The results of this study can be interpreted as a physical education teaching program has the effect of developing a more positive attitude towards the teaching profession compared to the alternative teaching certification group. Studies indicate that teacher candidates in the teaching program developed a more positive attitude towards the teaching profession than the candidates in the alternative teaching certification group. Similar to our findings, Bozkırlı and Er [20] concluded that attitudes of teacher candidates in the regular Turkish Language and Literature were significantly higher than teacher candidates in alternative teaching certification program of the Turkish Language and Literature. In line with these results, Dadand, Kalyon, and Yazici [21] indicated that faculty of education students had a higher attitude score towards teaching than students in the alternative teaching certification program. Students in the physical education teaching program participated in more classes and practices, and this may influence developing a more positive attitude towards the teaching profession. The difference in the duration of the education period, in other words, the possibility that the teacher candidates who are in the physical education teaching program have a longer time to develop an attitude towards teaching may have led to this result. Instructing classroom management, pedagogical knowledge, learning and teaching strategies, methods and techniques to teacher candidates in a short period within the scope of the alternative teacher education programs have been criticized [14]. Yıldırım and Ok [22] indicated that quantitative factors such as the number and duration of courses differ between the teacher education programs, and these factors have an impact on the quality of the teacher education program. Moreover, transferring these pedagogical knowledge to teacher candidates is not just related to quantitative factors but also some qualitative factors such as the content of the courses and the expertise of the instructors of the courses. Field-specific professional development courses can be seen as an important point in the development of teacher candidates. Bulca, Saçli, Kangalgil and Demirhan [23] maintained that the practical applications of the physical education would be the most useful within the courses related to the teaching profession knowledge provided by the field experts. However, alternative teacher education programs do not provide the most physical education specific field courses under the supervision of physical education field experts. In other words, the support of the physical education scholars in alternative teacher education programs is limited.

The reasons for enrolling the alternative teacher certification might be effective on responses of teacher candidates in alternative teacher certification program. Akar [24] reported that difficult working conditions and limited employment opportunities in other fields are major motivational sources of teacher candidates in an alternative teacher certification program to become teachers. Researchers previously reported that teacher candidates who selected the teaching profession voluntarily have higher attitude scores than those who selected it reluctantly in Turkish sample $[12,13]$. Thus, the lower attitude of teacher candidates in alternative teacher certification could be attributed to motivational sources for becoming a teacher.

In this study, although there is no statistically significant difference was observed between genders, the average score of females is higher than that of males. This result is parallel to some research findings. It was found that the attitudes of the teacher candidates did not differ by their genders in Turkish context [25]. Similarly, Eraslan and Çakıc1 [26] indicated that there were no statistically significant differences between male and gender teacher candidates in alternative teacher certification program. Pajares [5] emphasized that experiences have a critical role in the formation and development of belief systems such as attitudes. In this respect, when the subject is analyzed in terms of physical education and sports, the female and male teacher candidates to have a common sports culture may have led them to develop similar attitudes towards physical education and sports. Parallel to this explanation, Sandıkçı, and Öncü [27], explored that the attitudes of teacher candidates towards the teaching profession from different fields, and have concluded that gender does not differ only among physical education and sports teacher candidates.

This study presents the differences in attitudes towards teaching profession among Turkish physical education teacher candidates from physical education and alternative teacher education programs. Accordingly, attitudes of teacher candidates in physical education teaching program were significantly higher than participants in alternative teacher certification program. Thus, it can be concluded 
that the quantitative factors such as such as the number and duration of courses in alternative teacher certification programs and qualitative factors such as the support of the field experts to alternative teacher certification programs might be effective on results of this study. Based on the previous literature, it can be suggested that extending the period of the alternative teacher education program and contribution of physical education field experts to alternative teacher education programs may lead to increase in attitude among teacher candidates in these programs. This study has some methodological limitations. The sample represents an only central Anatolian region of the Turkey and sample size was relatively small. Moreover, it can be suggested to conduct a qualitative study among teacher candidates in an alternative teacher education program to explicate attitudes towards teaching.

\section{REFERENCES}

[1] H. Demirtaş, M. Cömert, N. Özer. Öğretmen adaylarının öz yeterlik inançları ve öğretmenlik mesleğine ilișkin tutumları, Eğitim ve Bilim, Vol. 36, No. 159, 96-111, 2011.

[2] G. V. Caprara, C. Barbaranelli, P. Steca, P. S. Malone. Teachers' self-efficacy beliefs as determinants of job satisfaction and students' academic achievement: A study at the school level, Journal of School Psychology, Vol. 44, 473-490, 2006.

[3] Ç. Kırel. Sosyal psikoloji, In: S. Ünlü (Eds.), Tutum ve tutum değişimi. Eskişehir: Anadolu Üniversitesi Açıöğretim Fakültesi Yayını, 2011.

[4] D. Deryakulu. Epistemolojik inançlar, In: Y. Kuzgun, D. Deryakulu (Eds.), Eğitimde Bireysel Farklılıklar, Ankara: Nobel Yayın-Dağıtım, 259-287, 2004.

[5] M. F. Pajares. Teachers' beliefs and educational research: Cleaning up a messy construct, Review of Educational Research, Vol. 62, No. 3, 307-332, 1992.

[6] T. R. Guskey. Professional development and teacher change. Teachers and teaching, Vol. 8, No. 3, 381-391, 2002.

[7] M. Matanin, C. Collier. Longitudinal analysis of preservice teachers' beliefs about teaching physical education, Journal of Teaching in Physical Education, Vol. 22, 153-168. 2003.

[8] L. L. Jones, A. E. Hayes. How valid are surveys of teacher needs, Educational Leadership, Vol. 37, 390- 392, 1980.

[9] P. Öksüzoğlu. Beden eğitimi öğretmen adaylarının öğretmenlik mesleğine ilişkin yeterlik algıları, Yayımlanmamış Yüksek Lisans Tezi, Mesin Üniversitesi Sağlık Bilimleri Enstitüsü, Mersin, 2009.

[10] M. Üstüner, H. Demirtaş, M. Cömert. The attitudes of prospective teachers towards the profession of teaching (The case of Inonu University, Faculty of Education), Education and Science, Vol. 34, No. 15), 140-155, 2009.

[11] N. Tsangaridou. Trainee primary teachers' beliefs and practices about physical education during student teaching, Physical Education and Sport Pedagogy, Vol. 13, 131-152, 2008.

[12] P. O. Taneri, A. Ok. Alandan ve alan dışından öğretmenlik sertifikası ile atanan yeni sınıf ögretmenlerinin sorunları, Eğitim ve Bilim, Vol. 39, No. 173, 418-429, 2014.

[13] M. S. Malow-Iroff, E. A. O'Connor, B. M. Bisland. Intention to return: Alternatively certified teachers' support, ideology and efficacy beliefs, Teacher Development, Vol. 11, No. 3, 263-275, 2007.

[14] L. Postareff, S. Lindblom-Ylanne, A. Nevgi. The effect of pedagogical training on teaching in higher education, Teaching and Teacher Education, Vol. 23, No. 5, 557-571, 2007.

[15] G. Yıldızer, İ. Yılmaz, D. Y. Solmaz, D. Şimşek. Teaching Styles Used by Teacher Candidates Studying in Physical Education and Alternative Teacher Certification Programs, Hacettepe University Journal of Education, Vol. 33, No. 1, 90-106, 2018.

[16] J. R. Fraenkel, N. E. Wallen, H. H. Hyun. How to design and evaluate research in education (8. Bs.), New York: McGram-Hill Companies, 2012.

[17] A. Erkuş, N. Sanlı, M. T. Bağlı, K. Güven. Öğretmenliğe ilişkin tutum ölçeği geliştirilmesi, Eğitim ve Bilim Dergisi, Vol. 25, No. 116, 27-33, 2000.

[18] R. W. Schutz, M. E. Gessaroli. Use, misuse, and disuse of statistics in psychology research, In: R. N. Singer, M. Murphy, L. K. Tennant (Eds.), Handbook of research in sport psychology, New York: MacMillan, 901-921, 1993.

[19] B. G. Tabachnick, L. S. Fidell. Using multivariate statistics (6th ed.), Essex: Pearson, 2014.

[20] K. Ç. Bozkırlı, O. Er. Türkçe ve Türk dili ve edebiyatı öğretmeni adaylarının öğretmenlik mesleğine ilişkin tutumlarının çeşitli değişkenler açısından incelenmesi, Turkish Studies-International Periodical For The Languages, Literature and History of Turkish or Turkic, Vol. 6, No. 4, 457-466, 2011.

[21] I. Dadandı, A. Kalyon, H. Yazıcı. Eğitim fakültesinde öğrenim gören ve pedagojik formasyon eğitimi alan öğretmen adaylarının öz-yeterlik inançları, kaygı düzeyleri ve ögrretmenlik mesleğine karşı tutumları, Bayburt Eğitim Fakültesi Dergisi, Vol. 11, No. 1, 253-269, 2016.

[22] A. Yıldırım, A. Ok. Alternative teacher certification in Turkey: Problems and issues, In: Sultana R. G. (Eds.). Teacher Education in the Euro-Mediterranean Region, New York: Peter Lang Inc, 259-276, 2002.

[23] Bulca, Y., Saçlı, F., Kangalgil, M., Demirhan, G. (2012). Beden eğitimi öğretmenlerinin öğretmen yetiştirme programına ilişskin görüşleri. Eğitim ve Bilim, 37(165), 81-92.

[24] Akar, E. Ö. (2014). Fen edebiyat fakültesi biyoloji bölümü mezunlari neden öğretmen olmak istiyor?. Kastamonu Ĕ̈itim Dergisi, 22(1), 259-272.

[25] Y. Çapa, N. Çil. Öğretmen adaylarının öğretmenlik mesleğine yönelik tutumlarının farklı değişkenler açısından incelenmesi, Hacettepe Üniversitesi Eğitim Fakültesi 
Dergisi, Vol. 16, 69-73, 2000.

[26] L. Eraslan, D. Çakıcı. Pedagojik formasyon programı öğrencilerinin öğretmenlik mesleğine yönelik tutumları, Kastamonu Eğitim Dergisi, Vol. 19, No. 2, 427-438, 2011.
[27] M. Sandıkçı, E. Öncü, E. Beden eğitimi ile diğer alanlardaki öğretmen adaylarının öğretmenlik mesleğine ilişkin yeterlik algıları ve tutumlarının belirlenmesi ve karşılaştırılması, Pamukkale Journal of Sport Sciences, Vol. 1, No. 4, 135-151, 2013. 